\title{
Blast Cell Proliferation
}

National Cancer Institute

\section{Source}

National Cancer Institute. Blast Cell Proliferation. NCI Thesaurus. Code C18061.

Multiplication or reproduction by cell division of immature precursor cells that have not achieved a fully differentiated state. (NCl) 